
mericana de la Universidad de Oviedo. Es autora del libro Daniel Moyano: la búsqueda de una explicación (1993) y editora del volumen Teatro de la emigración asturiana en Cuba (1997). Ha publicado artículos sobre diversos temas como la identidad de los criollos en el siglo XVIII,

CRÓNICAS DEL SIGLO XVI, el pensamiento político de la emancipación, y fundamentalmente sobre narrativa argentina contemporánea.

\title{
CUENTOS DEL SIGLO XX: JUAN SUÁREZ DE PERALTA A TRAVÉS DE CARLOS FUENTES
}

VIRGINIA GIL AMATE

La reflexión sobre la capacidad de los distintos discursos narrativos para dar cuenta de lo verdaderamente ocurrido ha sido insistente piedra de toque de la crítica de las últimas décadas del siglo XX. Para algunos teóricos del discurso histórico la historia no se construiría sobre los sucesos acaecidos, es decir vividos por alguien, sino a partir de la información documentada y contrastada. Por ello el hecho histórico no sería previo a la construcción de lo histórico sino resultado de esa misma construcción. La historia parte, entonces, del archivo, del documento y el historiador de la información allí atesorada, y considerada objetiva, para con ello conocer lo que ha pasado ${ }^{1}$. Ahora bien, otros autores matizan el asunto y plantean que la historia sería un tipo de discurso con unas características concretas y definidoras de su naturaleza diferencial, siendo su característica básica que el hecho narrado, avalado por la evidencia documental y revelado por la existencia de varios discursos posibles sobre los mismos acontecimientos, es (fue) verdadero. El hecho, en este caso, aunque dado por la forma narrativa, emana de la propia realidad, de lo que efectivamente sucedió ${ }^{2}$. Por su parte los teóricos de la literatura han insistido en aseveraciones que, en definitiva, declaraban la inexistencia de cualquier realidad no lingüística y decretaban los pactos de lectura para definitivamente dudar de lo pasado y creer en las estrategias narrativas, en la absoluta autonomía del discurso ${ }^{3}$.
La creación literaria suele abrirse caminos entre las construcciones teóricas, pero aún así en los últimos años también los escritores se han visto en la necesidad de explicar el fin ontológico que persiguen con la escritura. En esos juicios ha podido disputarse el lugar ocupado tradicionalmente por la filosofía ${ }^{4}$ o desdibujar las fronteras entre la disciplina histórica y la ficción ${ }^{5}$. Concretamente Carlos Fuentes, en 1993 editaba simultáneamente un volumen de ensayos, Geografía de la novela ${ }^{6}$, y uno de cuentos, El naranjo ${ }^{7}$. Los ensayos analizaban la capacidad de la ficción narrativa como medio de conocimiento y cauce que abría posibilidades de futuro, mientras en los relatos llevaba a la práctica esas ideas. En el ideario era fundamental la noción de que la ficción creaba posibilidades de realidad a partir de rellenar lo no sabido porque se perdió el rastro de las evidencias que buscan los historiadores pero, paradójicamente, quedaban los hechos, los que no emanan del discurso ni yacen en el archivo sino que perviven amoldados en la conciencia colectiva. Ese es, a mi parecer, el hilo conductor del relato «Los hijos del conquistador» ya que, sobre el pilar de unos hechos sucedidos en el siglo XVI -fundamentalmente la conquista de México por Cortés; el nacimiento de diferentes hijos del conquistador con distintas mujeres, indias y españolas; la suerte política que Hernán Cortés libró con España entre 1526 y 1545 , año en que el juicio de residencia que-
1 J. Le Goff, Pensar la historia. Modernidad, presente, progreso, Barcelona, Paidós, 1991.

2

H. White, El contenido de la forma. Narrativa, discurso y representación histórica, Barcelona, Paidós, 1992.

3

R. Barthes, El susurro del lenguaje. Más allá de la palabra y la escritura, Barcelona, Paidós, 1987.

4

Planteamiento de Juan José Saer en la conferencia recogida en W. AA., Encuentros hispanoamericanos. Realidad y ficción, Oviedo, Fundación Municipal de Cultura / Ayuntamiento de Oviedo, 1992, págs. 125-136.

R. Piglia, Crítica y ficción, Buenos Aires, Siglo Veinte, 1990.

C. Fuentes, Geografía de la novela, Madrid, Alfaguara, 1993.

7

C. Fuentes, El naranjo, Madrid, Alfaguara, 1993.

Crónicas del siglo XVI, cuento del siglo XX: Juan Suárez de Peralta a través de Carlos Fuentes VIRGINIA GIL AMATE 


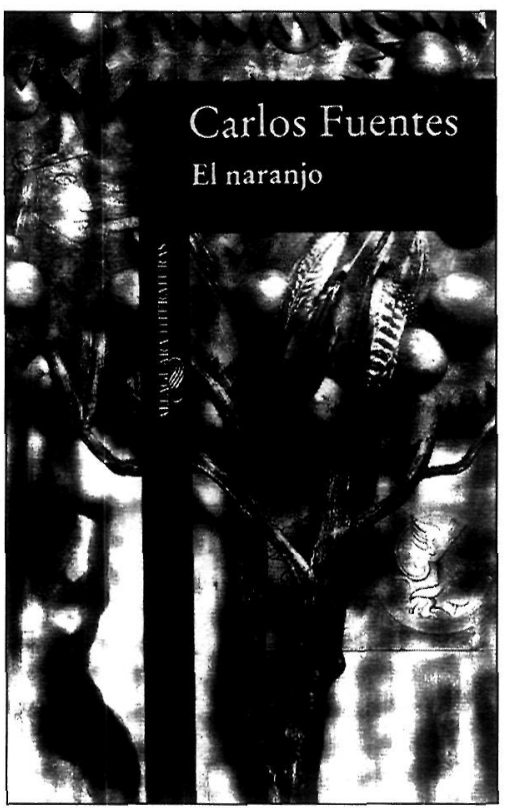

daría a la espera de resolución; el testamento cortesiano, firmado en 1547, el mismo año de su muerte; la llegada a México de su heredero, Martín Cortés, segundo marqués del Valle, en 1562, una vez que Felipe II le había reconocido sus bienes; y la definitiva represión de la casta de los conquistadores inmediatamente después de los sucesos protagonizados por los caballeros novohispanos en 1565- plantea un diálogo entre los dos hijos de nombre Martín de Hernán Cortés ${ }^{8}$. En sus parlamentos, ambos irán dando forma a esos sucesos desde la particular vivencia creada por Fuentes para ellos, en el mismo sentido expresado por el protagonista de El pozo de Juan Carlos Onetti:

8

Martín Cortés, hijo de Marina y Hernán Cortés, nació hacia 1522 probablemente en Coyoacan. Fue legitimado por bula papal en 1529 junto a sus hermanastros criollos Luis Cortés 10 Altamirano) y Catalina Pizarro. Fue caballero de la Orden de Santiago. Murió hacia 15691570; Marín Cortés, fruto del segundo matrimonio de Cortés con Juana de Zúñiga, nació en Cuernavaca en 1532. Viajó a España con su padre en 1540 y regresó a México, ya convertido en Marqués del Valle, en 1562 Se vio envuelto en la conjura de los caballeros criollos de 1565 , será trasladado a España, junto a su hermano Luis, para ser juzgado en 1567. Murió en Madrid en 1589. Cf., A. Muro Orejón, «Hernándo Cortés. Exequias, almoneda e inventario de sus bienes, con otras noticias de su familia», Anuario de Estudios Americanos, XXIII, 1966, págs. 537-609; J. L. Martínez, Hernán Cortés, México, FCE, 1992, principalmente "Los once hijos y el posible», cp. XVII, págs. 522527.

9

J. C. Onelti, El pozo, en Obras completas, pról. Emir Rodríguez

Crónicas del siglo XVI, cuentos del siglo XX: Juan Suárez de Peralta a través de Carlos Fuentes VIRGINIA GIL AMATE

Los hechos son siempre vacíos, son recipientes que tomarán la forma del sentimiento que los llene?.

Unas emociones que, en «Los hijos del conquistador», conforman una doble memoria colectiva (y con ello estamos ante el segundo elemento de variación de la realidad) sobre los conflictos sostenidos desde la fundación de la Nueva España hasta el presente de México. En este relato no se duda de lo sucedido, no se denuncia como falso el pasado histórico, no hay un regodeo literario en lo poco verídico que es lo verdadero... no se trata de eso sino de destacar que los hechos desencadenan percepciones que se suspenden en el tiempo, formando mentalidades que asumen su ser en el mundo más allá del suceso

Monegal, Madrid, Aguilar, 1970-1979, pág. 64 (1º ed. Montevideo, Signos, 1939).

\section{0}

Fernando Benítez había destacado la condición representativa de los hijos de Cortés, en un juicio que tiene puntos en común con los tipos propuestos en el relato de Carlos Fuentes: «Los hijos principales de Hernán Cortés, el moreno y el blanco, constituyeron dos prototipos. El bastardo establecía una larguísima sucesión de mestizos para los cuales, lejos de significar su sangre indigena una fuerza creadora y esti- mulante, suponía inseguridades fundamentales. A su vez, el legítimo iniciaba una cadena interminable de criollos holgazanes y ausentistas, cuya razón de prevalecer sobre los demás se apoyaba tanto en su linaje de nuevos aristócratas como en la riqueza que habían heredado casi siempre a costa de ciertos esclavos sometidos por unas hazañas en las que la brutalidad se confundía con la intervención milagrosa de la voluntad divina», BENÍTEZ, F., Los primeros mexicanos, México, Era, 1976, págs. 177-178, ( $1^{a}$ ed., El Colegio de México, 1953). que motivó ese sentir. La narración de Carlos Fuentes concentra dos visiones, la de Martín II, el mestizo, y la de Martín I, el criollo. Martín II aludirá a la única «historia verdadera», la que emana de lo vivido y se trasmite de unos individuos a otros en forma de recuerdo, y por tanto nunca es algo pasado sino actualizado permanentemente por la querencia o la rabia que lo sostiene:

La historia verdadera, que no los polvosos archivos, lo dirán un día. La historia viva de la memoria y el deseo, hermano, que ocurre siempre ahoritita mismo, ni ayer ni mañana («Los hijos del conquistador», pág. 77)

Sobre la ruptura de los pilares cronológicos del discurso histórico ("lo que ocurre siempre ahoritita mismo») se erige la ficción, que puede moverse con soltura a través de las memorias colectivas, intangibles pero más difíciles de derribar que los contundentes muros de cualquier biblioteca. Los dos personajes están construidos de forma que tanto remiten a sus sujetos históricos ${ }^{10}$ como al arquetipo mental que representan, por eso pueden recrear momentos del pasado y a la par situarse más allá de sus propias vidas. Esta transcronía permite que los personajes detallen su nacimiento y muerte siguiendo la estela rulfiana de los difuntos locuaces porque su tema de debate no se ha acabado todavía. Pero sobre todo queda asentada en el uso atemporal de la lengua y en la numeración de los hablantes homónimos que amplifica el linaje a toda una genealogía, criolla o mestiza, surgida (y heredera) de la conquista.

Las voces de los hermanos seguirán un sinuoso curso que comienza y termina en soliloquios. En medio se producirá la conversación, dificultosa en las primeras intervenciones en las que el mestizo azuza y pregunta al criollo sin que este se digne a responder, mientras el criollo inquiera, también, pero no distinga como receptor natural a su hermano. Es a partir de la tercera intervención de ambos cuando, al calor de los insultos, comienza una disputa. Hablan, con la subceptibilidad a flor de piel, y el debate ocasiona que, mientras el padre, Hernán Cortés, cobra la condición humana que el mito le niega y por tanto hay atisbos de que pueda ser aceptada de una vez su figura; las madres, Juana de Zúñiga y Malinche, van adquiriendo una dimensión simbólica en función de la sangre indígena o española. 
Existen dos premisas de partida que enfrentan a los hermanos: el criollo no permitirá que el mestizo insulte a Juana de Zúñiga, porque para eso se basta sólo; y el mestizo impedirá que el criollo se entusiasme con la conquista. Todo el parlamento de Martín I de ataque a Juana de Zúñiga es un recorrido alegórico por el catálogo de quejas que poblaron el imaginario de los primeros escritores criollos de Nueva España. Dice Martín I:

No sabía entonces que mi propia madre Juana de Zúñiga, imperiosa y arrogante [...] se convertiría, al morir nuestro padre, en la urraca despiadada de sus propios hijos («Los hijos del conquistador», pág. 81).

Eco del idéntico sentimiento que guía el «Llanto por la Nueva España» del poema inconcluso Nuevo Mundo y conquista de Francisco de Terrazas (c. 1580), salvo que la «madre» se encarna en una Nueva España concebida como entidad hispana por fuerza de conquista:

Madrastra nos has sido rigurosa,

Y dulce madre pía a los extraños,

Con ellos de tus bienes generosa,

Con nosotros repartes de tus daños.

Ingrata Patria, adiós, vive dichosa

Con hijos adoptivos largos años.

Que con tu disfavor fiero, importuno

Consumiendo nos vamos uno a uno. ${ }^{11}$

O de los airados reproches de Baltasar Dorantes de Carranza en Sumaria relación de las cosas de la Nueva España (1604):

¡Oh Indias! madre de extraños, abrigo de forajidos y delincuentes, patria común a los innaturales, dulce beso y de paz a los recién venidos, lisonja de los que se precian, hartura de los hambrientos, paño con que cubrís y vestís a los desnudos.

¡Oh Indias! madrastra de vuestros hijos y destierro de vuestros naturales, azote de los propios, cuchillo de los vuestros...12

Sustentando, finalmente, el punto de vista estructurador del Tratado del descubrimiento de las Indias y su conquista (1589) de Juan Suárez de Peralta ${ }^{13}$ que no es otro que el de retratar la disolución del inicial orden social novohispano por obra de la legislación peninsular.

«Los hijos del conquistador» sigue el rastro del curso que tomo la historia novohispa-

na desde la denegación del poder político a Hernán Cortés con el nombramiento de Antonio de Mendoza como primer virrey de Nueva España en 1535, y de las sucesivas leyes y cédulas reales que desde la década del 40 fueron mermando los privilegios de conquista hasta la total extinción de las primeras herencias, hacia 1570 , y la consecuente defenestración de los grandes encomende$\operatorname{ros}^{14}$. Sin olvidar, eso sí, otros hechos que atañen al comportamiento de los descendientes de los conquistadores, en este caso la vulneración del testamento cortesiano ${ }^{15}$ por parte de Martín Cortés, segundo marqués del Valle:

Bien me guardé, en cambio, de hacer válidas las cláusulas donde mi padre me encargó liberar a los esclavos de nuestras tierras mexicanas y restituirles las mismas a los naturales de los pueblos conquistados. Arrepentimientos de viejo, me dije. Si los cumplo, me quedo sin nada. ¿Le pedí perdón? Por supuesto. Mala persona no soy... ( «Los hijos...», pág. 68)

Reconozco que violé el testamento de mi padre, para evitarle el despilfarro de indios y tierras en nombre de no sé qué humanismo senil desordenado («Los hijos...», pág. 81)

Para aproximarse a esta época el relato de Fuentes transcribe, de forma crítica, la narración de Suárez de Peralta, el cronista novohispano del que Georges Baudot destacaba, con justicia, su «alucinante imaginación» ${ }^{16}$, el mismo «mediocre e inexacto historiador que, a lo sumo, repite mal lo que otros dijeron bien» según el juicio sumarísimo de González Peña ${ }^{17}$. La recuperación de este texto, de tan dudosa calidad historiográfica que difícilmente sopesaría su contraste con los datos, indica que Fuentes selecciona deliberadamente un discurso en el que no prima la información objetiva sino lo subjetivo, lo sentimental y lo pasional. Con el Tratado..., escrito en España el mismo año en que moría, también en España, el segundo marqués del Valle, Suárez de

11

TERRAZAS, F., «Llanto por la Nueva España», en DÍAZ-PLAJA, G., Tesoro breve de las letras hispánicas. Serie Ultramar 1, Madrid, Editorial Magisterio Español, 1974, pág. 149.
12

DORANTES DE CARRANZA, B., Sumaria relación de las cosas de la Nueva España con noticia individual de los conquistadores y primeros pobladores españoles, pról. Ernesto de la Torre Villar, México, Porúa, 1987, pág. 105. $1^{19} \mathrm{ed}$. México, Imprenta del Museo Nacional, 1902)

13

J. Suárez de Peralta, Noticias históricas de la Nueva España, edición y estudio preliminar Justo Zaragoza, Madrid, Imprenta de Manuel G. Hernández, 1878; Tratado del descubrimiento de las Yndias y su conquista, ed. Giorgio Perisinotto, Madrid, Alianza, 1990. Todas las citas pertenecen a esta edición.

14

Cf. A. Moreno Toscano, siglo de la conquista», Historia General de México, vol. II, México, El Colegio de México, 1977 (2ª ed. corregida), págs. 1-81.

15

M. Cuevas, Testamento de Hernándo Cortés, México, Imprenta del Asilo «Patricio Sanz», 1925. Para cuestiones relacionadas con los bienes de Cortés vid. A. Muro Orejón, loc.cit.

16

G. Baudot, «Malintzin, imagen y discurso de mujer en el primer México virreinal», en GLANTZ, M., La malinche, sus padres y sus hijos, México, Taurus, 2001, pág. 63.

17

C. González Peña, Historia de la literatura mexicana, México, Porrúa, 1969, pág. 30

Crónicas del siglo XVI, cuentos del siglo XX: Juan Suárez de Peralta a través de Carlos Fuentes VIRGINIA GIL AMATE 


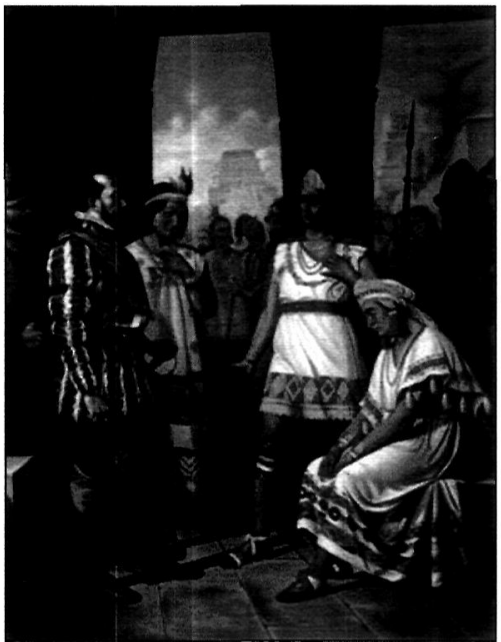

Hernán Cortés.

18

Para el estudio del mito en la obra de Carlos Fuentes vid. F. J. Ordíz, El mito en la obra narra tiva de Carlos Fuentes, León, Universidad de León, 1987.

\section{9}

Pasajes estos que irritaban a Fernando Benítez: "Suárez de Peralta, que nos ha dejado, como testigo cercano de los hechos, una relación pormenorizada de todo lo ocurrido, aprovecha la ocasión para componer una de las blandas y llorosas escenas que adornan con tanta profusión su relato», op. cit., pág. 211.

\section{0}

Tanto las Leyes Nuevas como la cédula de 1548 relativa a la abolición de la esclavitud indígena ocasionan que entre 1551 y 1561 se produzca la liberación de miles de esclavos indígenas y se transformen las tradicionales vinculaciones entre los encomen deros y sus siervos. Cf. Moreno Toscano, loc. cit., págs. 55-60 Sobre las controversias ocasionadas por la legislación de la corona en materia de esclavitud indigena y encomiendas puede consultarse R. Konetzke, «La política indigena de españoles $y$ portugueses", en América Latina. II La época colonial, Madrid Siglo XXI, 1981 (1 $1^{\mathrm{a}} \mathrm{ed}$. en castellano revisada, 1972), págs. 153-194.

Crónicas del siglo XVI, cuentos del siglo XX: Juan Suárez de Peralta a través de Carlos Fuentes VIRGINIA GIL AMATE
Peralta, retrataba con nostalgia una época perdida para siempre: la gestada en Nueva España a partir de la conquista, cuya élite socioeconómica la formaron los principales conquistadores y después sus descendientes, y narraba, sin mesura alguna, desde el punto de vista de esta segunda generación que heredaron los bienes y disfrutaron ociosamente de ellos. La reconstrucción de esta época, sin duda parcial y, a veces, amañada que ofrece Suárez de Peralta no empaña que su Tratado... trasmita un fresco de la vida de los grandes encomenderos, una semblanza de la mentalidad de los primeros caballeros criollos y que además desvele la afectividad del narrador. Así, esta crónica $\tan$ falsa revela una memoria verdadera, la de Juan Suárez de Peralta.

Por su parte, Carlos Fuentes construye un mito ${ }^{18}$ de origen a través de la ficción, aproximándose a la formación e inicial andadura de la Nueva España a partir de un doble diálogo, el narrativo, mantenido por los personajes, y el argumentativo establecido entre el propio relato y el Tratado... No vuelve a escribir Fuentes lo ya escrito, porque la evidencia del pasado no está sujeta a los hechos documentados sino a la vivencia de los mismos que le proporciona Suárez de Peralta, tan sólo distribuye el texto cronístico en los parlamentos de los Martines. Es decir, adopta el texto y lo adapta a los hablantes del relato para con ello, en primer lugar, ampliar la carga crítica que el cronista reservaba únicamente para la justicia peninsular; en segundo, forzar una reflexión política sobre el origen de la que estaba ajeno el cronista $y$, en tercero, marcar el periodo que se extiende desde la década del 30 a la del 60 del siglo XVI como aquél en que se pudo cambiar el curso de la historia mexicana si sus protagonistas no hubieran sido como fehacientemente los retrata -y se retrata- Suárez de Peralta. Este es el segundo precepto básico del discurso histórico que Fuentes vulnera: su ficción baraja posibilidades, no se deja coaccionar por lo que pasó adentrándose (en este relato y todos los que componen el volumen El naranjo) en el «imposible histórico», dejando que campe por sus fueros la premisa «qué hubiera pasado si...»
El hecho de que el texto de un sólo cronista pueda dividirse en dos hablantes es más una exhibición de la sagacidad crítica de Fuentes que de su maestría literaria, ya que es el propio Suárez de Peralta el que se muestra como un sujeto escindido tanto estéticamente, alternando pasajes líricamente emotivos ${ }^{19}$ con otros en que da rienda suelta a un campechano prosaísmo; como ideológicamente, puesto que puede jactarse frente a los españoles peninsulares de su ligazón criolla con los naturales, aludiendo a las amas de cría indígenas que tuvieron los criollos y en paralelo protestar, a lo largo del Tratado..., por las medidas de la corona para acabar con la esclavitud de esos mismos indígenas ${ }^{20}$.

Veamos los cambios que sufre la crónica matriz merced a esas adaptaciones.

Martín II, el mestizo, resume el capítulo XXIV del Tratado... dedicado a la riqueza de México. Su voz aquilata, pero no elimina, el orgullo exhibicionista del criollo novohispano al verse obligado a suprimir la anécdota de carácter personal. Pierde con ello el relato la gracia de la crónica porque el tipo humano que ésta dibujaba se sacrifica al arquetipo representado por Martín II. La selección del receptor es la que le permite a Fuentes soslayar la información característica de la crónica de Indias, con ello un recurso técnico le permite salvar el hiato temporal entre el siglo XVI y el XX. En resumidas cuentas, el personaje habla para su hermano, cuya competencia en el conocimiento de los asuntos novohispanos es idéntica a la suya; mientras el cronista, escribía para un receptor que incluía a los no peritos en Indias, de ahí su demora en la descripción de los productos americanos. Finalmente, el resentimiento que caracteriza al tipo encarnado en Martín II permite conservar la acidez de Suárez de Peralta hacia los españoles que prosperaron de la nada, pero lo que en el cronista novohispano era un prejuicio clasista ligado al hecho de conquista, en el personaje mestizo se transforma en un recelo étnico, sin embargo, ambos se verán traicionados por sus propias explicaciones porque, si el cronista negaba la existencia de pobres en Nueva España y el personaje decretaba la inexistencia de mendigos españoles en ambos discursos aparecerá la miseria extendida a todos los estratos étnicos. En este punto de nuevo aparecen los matices ya que la indiscreción propia del estilo de Suárez de Peralta 
se troca en amargura en Martín II, con la primera se escapa, aparentemente, un nombre propio, con la segunda se señala deliberadamente:

Con esta abundançia no abía pobre, y los que en esta ocasión se declararon y determinaron a andar pidiendo limosna, la adquirieron de manera que ubo pobre, de los que andaban a pedir, que hizo mayorazgo en España de más de trezientas mil de renta. Y por no agraviar no señalo en qué parte y quién, que sería escandalizar a sus hijos y nietos, questán en muy buen ábito y posiçión de caballeros, y otros muy ricos, que quedaron en la tierra y sean azendado y tiene[n] hijos en ella. No es de maravillar ganasen tanto, porque yo oy dezir a biejos que la menor limosna eran quatro reales, que llaman medio peso. Y de aquí arriba dauan y munchos texuelos de plata de a marco, y dávanles mantas, una pierna, quellos después bendían. Aún oy en la Nueba España, a lo menos desde el año de setenta y nuebe que yo bine della, la más baja y menos y más ordinaria limosna que se da a los españoles, es de medio real de plata, porque no ay cuartos, ni los naturales saven qué cosa sea. Y digo berdad, çierto, que quando bine a España, que desembarqué en Sanlúcar de Barrameda, en casa del excelentísimo duque de Medina dondestube algunos días, bí los cuartos y baler que mespanté dije: «¿̨s posible questa moneda bale y por ella se halla de comer?» Espantéme porque tal no bí en México, donde naçí, puesto que mi padre era de Abila y mi madre de Nabarra. [...]

Corre una moneda que llaman cacao, la qual es una fruta que dan unos árboles, los quales se tiene por muy principal hazienda. Estos se dan en tierras calientes, y son muy delicados, y tanto, que si acaso bienen eladas, se yelan. Es el árbol del tamaño de un naranjo, la hoja es diferente, larga como de un jeme, y ancha de tres dedos; el berde no es muy claro, ni él es muy copado. Da la fruta cadaño y es desta suerte: naçe en maçorcas, y dentro está esta fruta ques la pepita. Son como almendras, aunque más chicas y más ynchadas, el color pardito, quebradas; tienen una cáscara más gruesa que la de la almendra, lo de dentro, la carne, es a piernas. Esta fruta sirve de moneda y con ella se compra dendel comer hasta el bestir. Balen de ordinario de ochenta hasta çien almendras destas un real. Béndense por cargas; bale la carga a treynta y a beynte y ocho pesos de a ocho reales. $Y$ ay cacao de más y menos balor la carga, como es el de Guatimala, y el de aquella privinçia tienen por mejor, y este bale, de ordinario, a tres y a quatro pesos más. El de la costa de la Nueba España, como es Colima, y estotra costa de Huatulco, bale menos. Es trato que a enriqueçido a munchos y dádoles a çien mil duca- dos. Y ombre a abido, que, fue Alonso de Billaseca, que alcanço un millón de pesos de a ocho reales, empeçando con muy poco caudal, y tanto, que en los mercados se ponía tendido en una estera que llaman petate, a bender el cacao por menudo, contándolo. El subióle a lo que e dicho. Esta fruta se come y se beve, y ésta es la causa porque se acaba, y cada año se coje nueba... (Tratado..., cp. XXIV, págs. 166167)

México era ciudad riquísima, y en ella no había españoles pobres [...]. Ya se sabe que las fortunas en México se hacen pronto, pero en estos años después de la Conquista, bastaba ser pobre y español para meterse a limosnero y fundar al poco tiempo un mayorazgo, pésele a los hijos y nietos, hoy ennoblecidos, de aquellos pordioseros. Éste es país, también lo sabes, donde el dinero crece en los árbo-

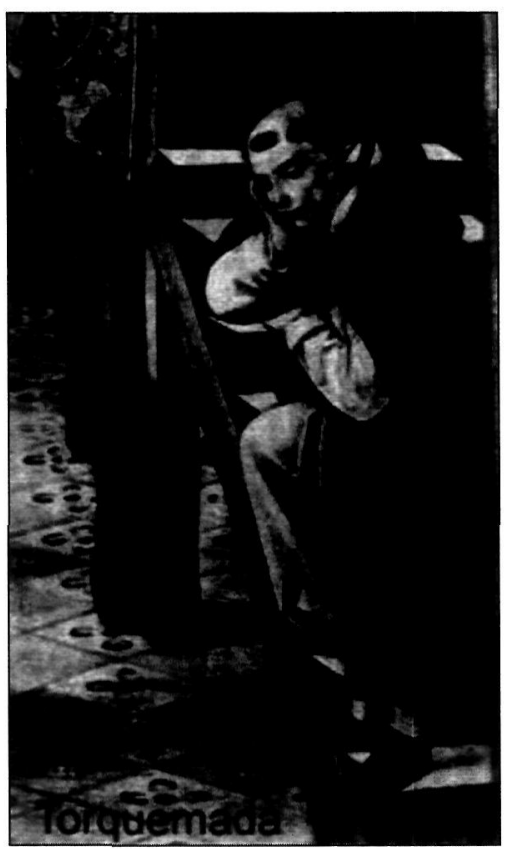

Torquemada. les, pues la moneda corriente de los indios es el cacao, que se da en mata del tamaño del naranjo y con una fruta de tamaño de almendras, cien de las cuales valen un real. Basta acostarse en un petate en el mercado a vender cacao para acabar, como el caballero Alonso de Villaseca, con un millón de pesos de hacienda ( «Los hijos del conquistador», págs. 83-84)

A continuación el personaje narrará el recibimiento que México le propinó, en 1562, a Martín Cortés, segundo marqués del Valle, para ello transcribirá las palabras de Suárez de Peralta conservando sus latigazos verbales pero amplificando, hacia una intencionalidad política, la mera descripción habida en la crónica sobre las dudas protocolarias surgidas en el encuentro entre el heredero de Cortés y el virrey de México, a la sazón Luis de Velasco, el viejo. Para el incisivo Martín II, el encuentro entre el heredero de la tierra conquistada y el transitorio representante del rey en Indias, tiene un cariz simbólico; para el trivial cronista los gestos del recibimiento no son más que una cuestión de educación que le sirve para lanzar una de las múltiples andanadas reservadas para el marqués a lo largo de la crónica:

Llegado el marqués a Yucatán con su mujer, luego se despachó nueba a México, con la qual se regozijarom todos y se holgaron con gran estremo. Y aquella noche que bino se hizieron luminarias, y desde allí en adelante trataron -la çiudad y el birrey- de las fiestas
Crónicas del siglo XVI, cuentos del siglo XX: Juan Suárez de Peralta a través de Carlos Fuentes VIRGINIA GIL AMATE 
que se le abían de hazer [...] Bino por tierra, y en todos los lugares le reçebían con grandes fiestas. Los cavalleros de México hizieron munchas galas, y le salieron a recebir el que menos a Cholula [...]

El benía acompañado de toda la flor de la tierra, y benía con él don Luis de Belasco, hijo del birrey. Çierto era muy de ver la grandeça con que fue reçebido y acompañado. Gastosé dinero - que fue sin cuento- en galas, juegos y fiestas [...] Después de la fiesta que este cavallero [Hernán Gutiérrez Altamirano] le hizo, suçedióle otra que la çiudad de México le hizo, de jente de a cavallo, en el campo, de libreas de seda rica y telas de oro y plata que fue costosísima. Más de trezientos de a cavallo, en muy ricos cavallos y jaezes hizieron una muy conértada escaramuça de munchas ymbençiones que duró munchas oras. Y luego toda aquella caballería, bestidos como estavan, le binieron acompañando hasta la çiudad, com más de otros dos mil de a caballo, de capas negras. Era cosa muy de ber. Desta manera llegó a la çiudad. Estaban las señoras -y las que no lo eran- a las bentanas, riquísimamente ataviadas, con munchas joyas de oro y doseles.

Desta suerte fue a palaçio donde estaba el birrey don Luis de Belasco, el qual andaba malo de la gota, y le salió a reçevir con un bordón hasta la puerta de la sala grande. Allí se pidieron las manos y se abraçaron estubierom porfiando sobre quál tomaría el lado derecho, y al fin quedó con él el birrey quera por estremo bien criado. Aquella noche le dio de çenar com el cumplimiento quel birrey hazía sus cosas y magestad. Después se fue el marqués a su casa, y el birrey se quedó en la suya. (Tratado...., cp. XXIX, págs. 186-188) ... Mira: para alagarte, yo mismo contaré la manera como regresaste a México, a los treinta años de edad, en el año 1562, en medio de la alegría de todos los hijos de los conquistadores pues ya éramos al tiempo de una segunda generación y en ti ellos veían la justificación de sus riquezas mexicanas cuando las habían y la justicia en reclamarlas cuando no. Reuniéronse todos en la plaza mayor de la ciudad de México para recibir al hijo criollo del conquistador. Todos pusieron de su peculio [...]. Esto es para indicar con qué reventón fue en efecto recibido mi hermano Martín Cortés al llegar de España y entrar a la plaza mayor de México llena de más de trescientos jinetes en muy ricos caballos y jaeces, con libreas de seda y telas de oro, que fingieron en honor del hijo del conquistador lides y escaramuzas. $Y$ luego entraron dos mil jinetes más con capas negras para hacerla de emoción, y a las ventanas salieron las señoras (y las que no lo eran también) ataviadas con joyas y doseles. El propio virrey Luis de Velasco salió del palacio a recibir a mi hermano, abrazándolo, pero si el Virrey miraba alrededor de la plaza lo que sólo le daban de prestado, mi hermano miraba lo suyo propio: el centro de la capital de Moctezuma, donde nuestro padre se quedó con los palacios de Axayácatl, para construir las Casas Viejas para sí y los suyos y, sobre el palacio de Moctezuma, las Casas Nuevas o sea el palacio del cual salía hoy el propio Virrey a recibirte, Martín hermano («Los hijos del conquistador», págs. 83-84)

En paralelo a esa adaptación se produce una ampliación del punto de vista, porque Martín II incrusta su mirada en el texto de Suárez de Peralta para mostrar lo que el criollo no vio o, al menos, no relató y así el fasto virreinal de la población hispana convive con los sometidos o desheredados, indígenas o mestizos. Claro que la amplitud de esta visión no está exenta de prejuicios que dirigen la focalización hacía una estricta dicotomía, a través de ella veremos una sociedad compartimentada en dominadores españoles y siervos mexicanos, en fasto hispano y miseria indígena, haciendo caso omiso de que, por ejemplo para no salirnos de los protagonistas del cuento, Martín Cortés el grande -trasunto histórico de Martín II- fue caballero de la orden de Santiago y por tanto un mestizo principal y la masa indigente novohispana no estuvo sólo integrada por indígenas, a ella también pertenecieron los «vaga mundos», «holgazanes» y toda una pléyade de desheredados españoles descendientes de conquistadores o primeros pobladores sin suerte:

Todo lo ví yo desde la obra que por entonces se iniciaba de la catedral de México, entre postes y mamparas, en nada distinto yo de los albañiles y cargadores que allí se hacinaban, ellos tan lejanos al lujo que te rodeaba, ellos sin la plata, ni el mayorazgo, ni las pepitas del cacao siquiera, sino con las caras arañadas por la viruela y las narices escurriéndoles mocos pues aún no se acababan de acostumbrar al vil catarro europeo. Y yo hermano, viéndote entrar rodeado de gloria a la ciudad conquistada por nuestro padre. Yo, hermano, parado en lo que quedaba del vasto muro azteca de las calaveras, sobre el cual comenzaban a levantarse la catedral. Dejé de mirar a los jinetes y los caballos. Miré a la gente mugrosa que me rodeaba, vestida de manta, descalza y con las frentes ceñidas de cordeles y las espaldas cargadas de costales, y pensé, Dios Mío, ¿cuántos cristianos vendrán algún día a orar a esta catedral, sin imaginar siquiera que en la base de cada columna del templo católico está inscrita una insignia de los dioses aztecas? («Los hijos del conquistador», págs. 84-85) 
La muerte de la Malinche, otro de los datos apuntados en el relato, opera también en el mismo sentido de fijar una imagen de la Nueva España como sociedad en la que se polarizaba lo español frente a lo indígena. Martín II avisa que vio morir a su madre «de viruela en 1527» (p. 66), sin embargo si el rastro de $\mathrm{Ma}$ rina se debilita a partir de 1526 su muerte no se producirá hasta años después, en $1541^{21} \mathrm{o}$ con mayor probabilidad en $1551^{22}$, hasta esa fecha vivió en la ciudad de México acorde a su condición de señora principal ${ }^{23}$. Por tanto en la cristalización de esas memorias colectivas que el relato transmite hay una construcción amoldada al fin literario que se persigue y asentada en la distorsión de los hechos históricos, ya avisó François Lopez, a propósito de otros asuntos, que «es muy cómodo descartar los hechos, porque estos suelen objetar, sin respeto a teoría alguna» ${ }^{24}$, por nuestra parte, $y$ atendiendo a la libérrima condición de un texto literario, colegimos que Fuentes también construye su propia historia erigiendo imágenes no menos creativas que las atesoradas en su intertexto.

Martín I había advertido, desde el inicio del relato, la tendencia de su hermano a recordarlo todo, mientras él se niega a conservar una memoria dolorosa, por eso, cuando le toca describir los inicios de su estancia en México, puede transcribir el contenido del Tratado... matizando levemente la redacción:

El marqués hazía plato a todos los caballeros y en su casa se jugava. Y aun se dio en brindar, questo no se usava en la tierra ni savian qué cosa era; y admitióse este viçio con tanto desórden como diré. En la mesa se brindavan unos a otros; y era ley y se huardaba quel que no açetase el desafío luego le tomasen la gorra y se a hiziesen cuchilladas públicamente. Y si bebían y alguno acertaba a caer, perdía el preçio que se ponía. Era de manera esto que no lo sabré encareçer. En las comidas y çenas se tratavan de munchas faltas que se savían de algunos, aunquestubiesem presentes. Dieron también en hazer máscaras, que para salir a ellas no era menester más de conçertallo en la mesa y dízir: «Esta tarde tengamos máscara» y luego se ponía por obra y salían disfraçados çien hombres de a cavallo. Andavan de bentana en bentana hablando con las mujeres; apeábanse algunos y entraban en las casas de los cavalleros y mercaderes ricos que tenía[n] hijas o mujeres, hermosas, a parlar. Bino el negogio a tanto que ya andavan munchos tomados del diablo, y aun los predicadores lo reprehendían en los púlpi- tos. Y en abiendo máscara de disfraçados se ponían algunos a las bentanas con sus mujeres, y las madres con sus hijas porque no las hablasen libertades. Y bisto que no podían hablarlas, dieron en hazer unas zebratanas largas, que alcançaban con ellas a las bentanas, y poníanles en las puntas unas florezitas, y llevánbanlas en las manos, y por ellas hablaban lo que querían. Estas cosas se usaron después del marqués en la tierra, y era por ser él muy regozijado; que baliera más que no lo fuera, que tan caro le costó, y a todos. Procuró el birrey de remediar estas cosas de secreto, sin castigo y no pudo... (Tratado..., cp XXX, págs. 189-190)

¡Esto es lo que me gusta recordar! Imaginaos que en la gran ciudad de México se desconocía el brindis. A mí me tocó introducir en las cenas y saraos esta costumbre española. ¡Nadie en México sabía qué cosa era! Yo puse el brindis de moda, y no había reunión de hijosdalgo, descendientes de conquistadores o simples oficiales del virreinato, donde no se sucediesen desde entonces los brindis, en medio de la alegría, la borrachera y el desorden. iA ver quien aguantaba más, quién decía mejores donaires y quién se negaba a ir hasta el fin! Convirtióse el brindis en centro de todas las reuniones, y al que no aceptaba desafío, le quitábamos la gorra y se la hacíamos cuchilladas en frente de todos. Luego salíamos todos a las calles de México a hacer máscaras, otra costumbre que yo traje de España, en que salíamos a caballo cien hombres enmascarados e íbamos de ventana en ventana hablando con las mujeres y entrando a las casas de los caballeros y mercaderes ricos, a hablar con ellas, hasta que estos buenos hombres se indignaron de nuestro proceder y cerraron puertas y ventanas, mas no contaron con nuestro ingenio, que fue alcanzar los balcones de las mujeres con cerbatanas largas, con florecillas en las puntas, ni con la audacia de ellas, que desafiando órdenes paternas y maritales, se asomaron entre los visillos a mirarnos a los galanes. Puro regocijo fue en este tiempo mi vida en la capital de la Nueva España, alegrías, donaires, honores, y seducciones mil («Los hijos del conquistador», págs. 85-86)

De la crónica matriz se ha eliminado el tono de censura hacia la alegría celebratoria, pero no se ha traicionado al cronista puesto que su reprobación no partía de una austera moral. Suárez de Peralta goza describiendo el lujo novohispano. Sin cinismo alguno plantea que la paz en Indias depende de la feliz ociosidad de los grandes encomenderos y de la conservación de sus privilegios ${ }^{25}$. Por tanto no es una postura ética la que guía su censura sino una particular forma de encadenar narrati-
21

Cf. G. Baudot, "Malintzin...», pág. 73.

22

Cf. G. Baudot, «Política y discurso en la conquista de México: Malintzin y el diálogo con Hernán Cortés», Anuario de Estudios Americanos, Vol. XLV, 1988, pág. 81; y «Malintzin...», págs. $72-74$.

23

CF. G. Baudot, «Malintzin...», págs. 70-76.

24

F. López, «El libro y su mundo», en J. Álvarez Barrientos, F. López, e I. Urzainqui, La república de las letras en la España del siglo XVIII, Madrid, Consejo Superior de Investigaciones Científicas, 1995, pág. 68.

25

Tratado..., cp. XV, pág. 173.
Crónicas del siglo XVI, cuentos del siglo XX: Juan Suárez de Peralta a través de Carlos Fuentes VIRGINIA GIL AMATE 
vamente los hechos vividos, en donde el marqués del Valle juega un papel central en la caída de los caballeros criollos, porque durante su estancia se produce la represión y, en este punto que tratamos, por algo más concreto: tanta fiesta acabó con alguna que otra de las fortunas existentes alterando la pirámide social, desdibujando los estamentos surgidos de la conquista, los únicos legítimos para el conservador cronista:

Con la llegada del marqués a México no se tratava de otra cosa sino era de fiesta y galas; y así las abía más que jamás ubo. De aquí quedaron munchos empeñados y los mercaderes hechos señores de las haziendas de todos los más caballeros, por que como se adeudaron y no podían pagar a los plazos, davan las rentas a los mercaderes, que creo oy día ay empeñadas haziendas de aquel tiempo. Fue con grandísimo eçeso el gasto que ubo en aquella sazón (Tratado..., cp. XXX, pág. 189)

Por si esto fuera poco, Suárez de Peralta no se priva de destacar que él fue uno de esos patrocinadores de festejos y al rememorarlo parece que todavía siente el resquemor del gasto:

A cavo de muchos días arribó su navío en el quel yba su mujer para parir, a Yucatán, donde parió un hijo que oy llaman don Jerónimo Cortés, con el qual y la nueba de aber llegado a tierra, aunque muy lejos de México, se holgaron todos y dieron munchas albriçias, y luego trataron de su reçevimiento, de gastar en él sus haziendas, como lo hizieron, y aun a mí me costó no al que menos (Tratado..., cp. XXVIII, pág. 185)

La labilidad del cronista para condenar o ensalzar las fiestas novohispanas es proporcional a la hipocresía con que Martín I, en el relato, se ufana, como hemos visto, de lo que en materia de fiestas importó de España a Nueva España o se retracta, con hilarante cursilería, de lo mismo. El relato hace que el cronista y Martín I coincidan en su nula capacidad política, y además, como el personaje repite casi siempre las palabras y siempre la intención del cronista, se fija una hipotética mentalidad única para representar a los criollos principales del siglo XVI:

Crónicas del siglo XVI, cuentos del siglo XX: Juan Suárez de Peralta a través de Carlos Fuentes VIRGINIA GIL AMATE de cañas, carrera pública. Estaban con esto tan contentos que yo oy dizir a um ombre muy desenbuelto, tratando quam padre de todos era el Birrey don Luis: «Yo juro a Dios que si el rey enbiase a quitar a todos los pueblos y las haziendas, que los consolaua el birrey y hazía olbidar este daño, con hazer sonar un pretal de cascabeles por las calles, según están todos metidos en regozijos». Y tenía razón, porque la tierra estaua muy quieta y buena (Tratado..., cp. XV, pág. 173)

Por Dios Santísimo que yo no inventé la fiesta y el jolgorio de la colonia mexicana; por su Santísima Madre, que yo llegué a una capital enamorada ya del lujo y la fiesta, donde se corrían toros bravos en Chapultepec y los paseos a caballo se oían cascabelear por los bosques: justas, sortijas, juegos de cañas: el virrey don Luis de Velasco dijo que aunque el Rey le quitase a los criollos sus pueblos y haciendas, el propio Virrey se encargaría de consolarlos con hacer sonar cascabeles en las calles («Los hijos del conquistador», pág. 88)

De este modo la sorprendente, intensa y personal obra de Suárez de Peralta queda cristalizada en el arquetipo encarnado por Martín I. Indudablemente algo se pierde en el camino, por ejemplo los caóticos meandros de la percepción del orden virreinal por parte del cronista; y algo se gana de índole técnica, puesto que la ficción de Fuentes comienza a perfilar uno de sus juegos de espejos de mayor interés al recalar en la parte afectiva del Tratado... Veamos, Suárez de Peralta le dedica amplios y arrebatados párrafos a Alonso de Ávila, uno de los más destacados encomenderos de México ${ }^{26}$. Su ajusticiamiento, ocurrido en 1566, arranca tonos conmovedores en la crónica y, en el plan narrativo del cronista, su figura se alza como emblema de la disolución de su clase. Estos pasajes se repartirán en las intervenciones de los dos hablantes del relato. Surge así el distanciamiento, a través de Martín II, y la introducción de la ironía o la abierta chanza donde en el texto de partida había puro deleite provocado por la descripción física de Alonso de Ávila:

[al recibir Alonso de Ávila la sentencia de muerte] empeçáronle a destilar las lágrimas de los ojos por el rostro abajo, que le tenía muy lindo, y él que le curava con muncho cuydado; era muy blanco y muy jentil ombre, y muy galán, tanto que le llamaban dama, porque ninguna -por muncho que lo fuese- tenía tanta cuenta de pulirse y andar en orden. El que más bien se traya era él y com más criados; y podía, por- 
que era muy rico. Çierto que era de los más luzidos caballeros que abía en México (Tratado..., cp. XXXIII, pág. 206)

Nadie más seductor, sin embargo, que Alonso de Ávila, cuya riqueza de atuendo ni en las cortes de Europa se hallaba, pues al lujo de allá añadía la riqueza natural de un país de oro y plata, y a estos metales mexicanos, el contraste de la más blanca piel que en hombre alguno se viese, acá o allá: sólo las más blancas mujeres eran tan blancas como Alonso de Ávila, que quizás se veía más blanco aún en tierra morena, y lo que dejaba ver eran sus manos, deslumbrantes, que se movían y dirigían y a veces hasta tocaban, con una ligereza de aire que hacía al aire mismo parecer pesado, ay qué ligero el tal Alonso de Ávila, obligado a dar paso por la tierra sólo porque eran ricos y graves sus atuendos de damasco y pieles de tigrillos, sus cadenas de oro y su toquilla leonada con un relicario, todo ello aligerado, ya les cuento, por las plumas de la gorra y el retorcimiento de los bigotes que eran, ellos, las alas de su rostro ( LLos hijos del conquistador», págs. 86-87)

Consigue, además, hacer evidente la latente carga homosexual de la crónica y, de paso, profundizar en la identificación entre Martín I y el resto de criollos principales, sea Alonso de Ávila o el memorialista de todos ellos, Suárez de Peralta. Además, si en el Tratado.... se primaba la vista sobre otros órganos de percepción puesto que era del gusto del cronista describir los atuendos, la fisonomía, el marco escénico, para revivir desde su visualización el pasado inmediato, en «Los hijos del conquistador» se rescata la importancia de la mirada por medio de Martín II, él es el que observa, en el contexto del relato, a Martín I y a Alonso, y, en el reflejo metaliterario (no olvidemos que el hablante aludirá a los «espejos»), a quien mira es a Suárez de Peralta describiendo a Alonso de Ávila:

Intimaron Martín y Alonso; juntos organizaron y gozaron los brindis y las mascaradas; entre ellos se admiraron, como hidalgos jóvenes y ricos que se sorprenden a veces (como más de una vez los sorprendí yo, desde las sombras) admirándose entre sí más que a las mujeres que cortejaban; pujando por ganarse a una dama hermosa sólo para imaginarla en brazos del otro; culeando los muy cabrones para imaginarse cada uno en el lugar del otro; así de cerca se unieron Alonso de Ávila y Martín Cortés. Qué de extraño que en este ambientacho de lujo y fiesta, relajo y parranda, espejos y más espejos, perfumes y admiracio- nes mutuas, Martín y Alonso, Alonso y Martín el hijo y heredero del conquistador, el hijo pródigo de Hernán Cortés, abrazando al sobrino de otro ruidoso capitán de la Conquista, Ávila el encomendero, el pícaro que echó mano (mi mismísima madre lo vio y me lo contó) de las vestiduras de oro de Moctezuma, e hijo de Gil González, encomendadero y traficante de tierras que a los verdaderos conquistadores despojó de las suyas, coyote y prestanombres que escondió acuciosamente su riqueza sólo para que sus hijos, Alonso y Gil, la luciesen y gastasen, se uniesen en un torbellino de placeres... ( «Los hijos del conquistador», págs. 87-88).

Martín I contemplará la muerte de los hermanos Ávila desde la ventana de su prisión, lo que ve (lo que cuenta) es lo visto por Suárez de Peralta al acompañar hacia el cadalso a los Ávila, según apunta en el Tratado... El cuento recupera el plano formal de la crónica y recrea el afectivo. El texto matriz ha sido leve pero significativamente adulterado; primero, al convertir en actitud del personaje la somera descripción del cronista con respecto a Gil González de Ávila, destacando una vez más el relato que la mirada de Suárez de Peralta no abarcaba todo el horizonte novohispano sino el de sus intereses; segundo, al hacer que la reconvención del fraile hacia Alonso de Ávila esté motivada por su inadecuada preocupación estética cuando en la crónica su desasosiego era de índole familiar, con ello el relato juzga al cronista que en medio de la tragedia no deja de describir minuciosamente la indumentaria y el semblante del reo:

Llevaba Alonso de Abila unas calças muy ricas al uso, un jubón de raso, una ropa de damasco aforrada en pieles de tiguerillos, ques un aforro muy lindo y muy hidalgo, una gorra adereçada con pieças de oro y plumas, y una cadena de oro al cuello rebuelta, una toquilla leonada con un relicario, y ençima un rosario de Nuestra Señora, de unas cuentezitas blancas del palo de naranjo, que se las avía enbíado una monja en que rezase aquellos días questaba aflijido. Con este bestido le prendieron, que acavaba de comer y estava en una recámara donde tenía sus armas y jaezes, como tienen todos los cavalleros en México. Alli le prendieron y sin ponerse sayo ni capa le llebaron. $Y$ le prendió el mayor amigo que tenía, y su compadre, que era Manuel de Billegas, que en aquella sazón era alcalde ordinario. Salió cavallero en una mula, y a los lados frayles de la orden del señor Santo Domingo que le yban ayudando a morir, y él que no pareçía si-
Crónicas del siglo XVI, cuentos del siglo XX: Juan Suárez de Peralta a través de Carlos Fuentes VIRGINIA GIL AMATE 

salió hacia España con su padre en 1532, a la edad de ocho años, y regresaría a Nueva España en 1562 con treinta años, quizá el hijo criollo de Cortés, a su regreso, reproducía todas las desconfianzas y competencias habidas entre criollos y peninsulares. No olvidemos tampoco que Juan Suárez de Peralta se trasladó a España en 1579, desconociéndose hasta la fecha si alguna vez regresó a México.
Crónicas del siglo XVI, cuentos del siglo XX: Juan Suárez de Peralta a través de Carlos Fuentes VIRGINIA GIL AMATE no que yba ruando por las calles. Yba su hermano con un bestido de camino, de color berdoso el paño, y sus botas, como acavaba de llegar del pueblo. Sacarom primero a Gil Gonçález y luego a su hermano, desta suerte los llevaron derechos al tablado, sin traellos por las calles acostumbradas. Fue la grita de llanto la que se dio de la jente que los mirava, que era grima oyllos, qúando los bieron salir de la cárçel. Llegaron al tablado, se apearon y subieron en él, donde se reconçiliaron y los dichos que abían dicho. Ya que estaban puestos con Dios, hizieron a Gil Gonçález que se tendiese en el tablado, abiendo el berdugo, aperçevídose, y se tendió como cordero, y luego le cortó la caveça el berdugo, el qual no estava bien yndustriado y fue haziéndolo padeçer un rato, que fue otra lástima, y no poca.

Después de cortada, con la grita, lloros y solloços, bolbió la cabeza Alónso de Abíla, y como bio a su ermano descabeçado dio un muy gran sospiro, que realmente no creyó hasta entonçes que abía de morir, y como le vio así hincóse de rodillas y torno a reconçiliarse. Alçó una mano, blanca más que de dama, y empeçó a retorçerse los bigotes diziendo los salmos penitençiales; y llegado al del Miserere, empeçó a desatar los cordones de cuello, muy despaçio, y dijo, bueltos los ojos hazia su casa: "iAy, hijos míos y mi querida mujer, quáles os dejo!» Y entonçes fray Domingo de Salazar, obispo ques agora de las Felipinas, le dijo: "No es tiempo éste, señor, que haga vuesa merçed eso, sino mire por su ánima, que yo espero en Nuestro Señor, de aquí se yrá derecho a gozar dél; yo le prometo de dezille mañana una misa, ques día de mi padre Santo Domingo". Estonçes prosiguió en sus salmos, y el frayle se boluió al pueblo y dijo: «Señores, encomienden a Dios a estos cávalleros, quellos dizen que mueren justamente». Y se boluió a Alonso de Abila y le dijo: «¿ No lo diçe vuesa rnerçed así?» $Y$ él dijo que sí y se yncó de rodillas, bajándose el cuello del jubón y camisa. Era de ber lo que temía la muerte. Atáronle los ojos con una benda, y ya que iba a tenderse, alçó la mano, se descubrió y dijo de secreto al frayle çiertas palabras. Luego le tornaron a bendar y se puso como se avía de poner; y el cruel berdugo le dio tres golpes, como quien corta la cabeça a un carnero, que a cada golpe que le daba ponía la jente los gritos en el çielo. Desta manera acabaron estos desdichados cavalleros, dejando la tierra muy lastimada y confusa si morían, con culpa o sin ella... (Tratado..., cp. XXXIV, págs. 210-212).

Me asomé a la ventana. La plazuela se había llenado de menudo pueblo, contenido por jinetes. Entre dos filas de gente armada, pasaron los bermanos Ávila, Alonso y Gil. Llevaba Alonso mi hermano calzas muy ricas y jubón de raso y una ropa de damasco afo- rrada en pieles de tiguerillos, una gorra aderezada con piezas de oro y plumas, y una cadena de oro al cuello. Entre las manos distinguí un rosario hecho de cuentecitas blancas de palo de naranjo, que una monja le envió para los días de aflicción y él, riendo, me dijo que jamás lo tocaría. Junto a los hermanos iban los frailes de Santo Domingo. En su hermano Gil ni me fijé. Debía estar llegando de un pueblo cuando lo prendieron, pues su hábito era modesto, de paño verdoso, y usaba botas. Subieron los hermanos Ávila al tablado. Primero Gil se tendió con la cabeza adelantada, pero yo sólo tenía ojos para Alonso, mi amigo, mi compañero, viéndole allí, la gorra en la mano, la lluvia mojándole ese cabello que con tanto cuidado se enrizaba, y tan cuidado con su copete para hermosearse, viéndole y oyendo los torpes hachazos del verdugo hasta cortarle la cabeza de mala manera a Gil, entre los gritos y sollozos de la gente. Miró Alonso a su hermano descabezado y dio un gran suspiro, que hasta nuestra cárcel lo escuché y viéndole, se hincó de rodillas, alzó su blanca mano y empezó a retorcerse los bigotes como era su costumbre, hasta que el fraile Domingo de Salazar, que luego fue obispo de Filipinas y que le ayudó a bien morir, le dijo que no era ésta hora de hacerse los bigotes, sino de ponerse bien con Dios. Una voz entonó el Miserere, el fraile le dijo a la multitud:-Señores, encomiendo a Dios a estos caballeros, que ellos dicen que mueren injustamente. Le hizo una seña Alonso al fraile, éste se acercó al hombre hincado y algo escuchó en secreto. Le pusieron la venda. El verdugo dio tres golpes, como quien corta la cabeza de un carnero y yo me mordí la mano, preguntándome, ¿qué nos faltó, Alonso, qué nos - faltó decirnos, hacernos?, ¿nos vamos sin hacer algo que debimos hacer, acercarnos, hablarnos, querernos más?, ¿qué secreto le dijiste al fraile?, ¿me recordaste al morir?, ¿sólo te recordé yo?, ¿fuiste infiel a nuestra amistad en la hora de tu muerte?, ¿te moriste sin mí, mi adorado Alonso?, ¿ ¿me condenas a ser el que vive sin ti?, ¿deseándote, arrepentido de todo lo que no fue? («Los hijos del conquistador», págs. 105-107)

Como puede observarse en los fragmentos, Martín I sigue ocupando el lugar de Suárez de Peralta. Notable tramoya intertextual en la que el cronista es remplazado por un sujeto reprobado en su Tratado.... por su descortesía hacia los caballeros criollos y por su desconocimiento de las camarillas formadas en México ${ }^{27}$. A estas faltas imputadas por el cronista se suma la manera ambigua con que plasma la participación del segundo marqués del Valle en la conjura. Podrá negar su culpabilidad, en su intento de minimizar el delito de 
alzamiento de los criollos principales, y en paralelo dar detalles que comprometen tanto al marqués como a su planteamiento narrativo, puesto que aludirá a unas misivas en las que Martín Cortés anotaba alegremente planes y nombres.

El relato de Fuentes, ajeno a la parcialidad de Suárez de Peralta y pertrechado de otra finalidad, lee entre las líneas de la crónica y saca a la luz las contradicciones y devaneos del escritor novohispano. De este modo la alta clase criolla que pudo cambiar, nada más iniciada su andadura, el destino de México (según el planteamiento del relato), queda retratada en su irresponsabilidad e inhibición frente a la historia. Para su imaginativo fiduciario guarda también una sorpresa: si Suárez de Peralta cargaba las tintas contra Martín Cortés y sus cartas comprometedoras y dejaba flotar la inocencia de Alonso de Ávila, el relato cambia de fuente en este punto $y$, valiéndose de lo apuntado por Torquemada en Monarquia indiana (1615), Alonso es culpable según él mismo se declaraba en los papelitos que enviaba a sus admiradoras:

Presos todos los dichos, tomaronles las llaves de todas las caxas, cofres, y escritorios (que fue el total mal de Alonso de Avila) y fueron á sus casas, y no dexaron cosa en ellas que no catasen, y sequestrasen. En un escritorio de Alonso de Avila, se hallaron papeles, y villetes de algunas mugeres principales, que según yo he oído, era la munición más fuerte con que hacía guerra, por ser moço, galán y rico (aunque casado) que fueron la total destruición del desgraciado mancebo; porque con el encendimiento que cobraron con los papeles, cargo todo el golpe sobre él y a bueltas en el hermano...28

O bien por la yuxtaposición temporal que permite la ficción, o bien por imaginar qué pudo llegar a saber el marqués con el paso del tiempo, el relato permitirá a Martín I conocer el engaño y reconocerse, al igual que Suárez de Peralta a la luz de otras crónicas, como «un perfecto pendejo» ( «Los hijos del conquistador», pág. 111), incapaces de ver más allá de sus privilegios, reconcentrados ambos (el cronista y sus personajes) en unos placeres individuales que les impedían «desear», en terminología de Fuentes ${ }^{29}$, un futuro para México.

La fusión de personajes es la base técnica del relato de Fuentes y, curiosamente, podemos encontrar también su germen en el Tra- tado de Suárez de Peralta siguiéndole la pista a los pasajes que dedica a los oidores Alonso Muñoz y Luis Carrillo, los pesquisidores que, junto al licenciado Jaraba fallecido en el viaje, fueron enviados por Felipe II a Nueva España para que informasen sobre la conspiración de los caballeros criollos. Aparatosamente son descritos por el cronista como la cara y la cruz de la represión, donde uno se conmueve y otro disfruta de la ignominia que ambos han armado. Así de taxativo y simplista es el planteamiento de Suárez de Peralta sino fuera porque su descuido a la hora de escribir y sus rocambolescos análisis lo conducen, en el mejor de los casos, a la oscuridad expositiva y, en el peor, a permutar las cualidades que previamente les había asignado:

Estubo Muñoz en opinión en la tierra de cruelísimo, y Carrillo muy piadoso. Y eran allá en el secreto muy diferentes, según dezían, porque Muñoz en los tormentos se apiedava más y era muy blando, y Carrillo áspero y en las sentençias criminalísimo. Bivían con este engaño todos, que temblabam de Muñoz y le echavan millones de maldiçiones [...]Tenía el liçençiado Muñoz muy ásperas palabras, y con esto espantava, y el otro no (Tratado..., cp. XXXVIII, págs. 232-233)

Entre el barullo con el que el cronista maneja la información va fraguándose, sin embargo, un jugoso autorretrato en el que aflorará su laxitud moral. A saber, para probar esa diferente idiosincrasia que atribuye a los represores de sus propios amigos, no duda en narrar alegremente una anécdota personal en la que él mismo no tiene reparo en amenazar a un juez con denunciarlo ante Muñoz. De miedo muere esta víctima de Suárez de Peralta, al igual que Muñoz murió, según recoge Torquemada $^{30}$ (y no nuestro cronista), del temor provocado por la reacción del Monarca ante su actuación en Indias:

... tanto le temín que me acaeçio lo que diré. Yo abía servido el ofiçio de correjidor y alcalde mayor de la provinçia de Huatitlam, y cumplí en el tiempo questos señores estaban en México y di mi residençia. En el reçebir mis descargos, el juez a quien se avía cometido, que se llamaba Alonso de Solórzano, en çiertos descargos halléle sospechoso y que era de parte de um frayle que me seguía. Juréle que me avía de quejar al liçençiado Muñoz, como lo hize, el qual me dio una carta para él, que le dezía quen lo que lestava co-
J. de Torquemada, Monarquía indiana, intro. Miguel León Portilla, México, Porrúa, 1969, vol. I, Libro V, cp. XVIII, pógs. 631632.

29

«Entonces nos damos cuenta de que el pasado depende de nuestro recuerdo aquí y ahora, y el futuro de nuestro deseo aquí $y$ ahora. Memoria y deseo son imaginación presente: este es el horizonte de nuestros descubrimientos constantes, este es el viaje que podemos emprender cada día', C. Fuentes, Premio Miguel de Cervantes (1987), Madrid, Ministerio de Cultura / $\mathrm{Cl}$, 1988 , pág. 76

30 Monarquía indiana, Libro Quinto, cp. XX, pág. 638 .
Crónicas del siglo XVI, cuentos del siglo XX: Juan Suárez de Peralta a través de Carlos Fuentes VIRGINLA GIL AMATE 
31

«El cadáver del doctor Carrillo no debió arrojarse al mar, como dice el texto, pues según certificacion expedida por el obispo de la isla de Cuba, don Juan Castillo, en 28 de julio de 1572, los huesos de dicho doctor fueron exhumados de la sepultura donde estaban en la iglesia de San Cristóbal de la Habana, y remitidos á su esposa doña María, por conducto de don Luis de Velasco (hijo del virey del mismo nombre que fué de la Nueva España), y de fray Diego de Mendoza, en una caja de cedro del largo de una vara» J. Zaragoza, «Notas», nota 39 , pág. 33.
Crónicas del siglo XVI, cuentos del siglo XX: Juan Suárez de Peralta a través de Carlos Fuentes VIRGINIA GIL AMATE metido de mi residençia, que mirase lo que hazía porque le abían dicho no proçedía bien en ella haziéndome agrabio, y que él bendría a México donde sabría todo lo que pasava. Es çierto berdad que le dí la carta sábado al anocheçer y que el martes era ya enterrado de puro miedo. Le dio una calentura que por momentos me ymbiaba a llamar y me dezía: «Señor, ¿estaba muy enojado el señor liçençiado?» $\mathrm{A}$ las primeras preguntas le dezía yo que sí, y después que entendí su miedo, le consolava. No aprovechó, porquel murió, como digo (Tratado..., cp. XXXVIII, pág. 233)

El delirio de la inconsistencia entre el planteamiento esencial de su propia crónica, que no es otro que la defensa de los caballeros criollos frente a la terrible actuación de la Audiencia, y lo narrado, llega a su paroxismo al describir la despedida brindada, según Suárez de Peralta, a Muñoz por los caballeros criollos al abandonar México en 1568:

Salió toda la çiudad con el liçençiado Muñoz, acompañándole y los más caballeros. Fueron una jornada, donde se despidieron, y çierto que holgaran de que quedara en la gobernaçióm porque le abían tomado buena boluntad. El se enbarcó y su compañero y el birrey marqués de Falçes y los presos, mandando él toda la armada (Tratado..., cp. XXXVIII, pág. 233)

Amigo de la hipérbole, Suárez de Peralta no duda en pormenorizar la agonía final de Carrillo en el viaje de regreso a España, hasta el abandono del cuerpo en alta mar, porque producía temor y asco a «los muy asquerosos grumetes» (cp. XXXVIII, pág. 234), aunque no falten noticias sobre el desembarco del cadáver de Carrillo en La Habana ${ }^{31}$, y entretenido en descripciones morbosas pierde el rastro final de Muñoz:

Embarcados y hechos a la vela, a cavo de algunos días que navegavan, dio al doctor Carrillo una apoplejía terrible, que pareçe que usó Dios aquí milagro. Quitóséle la habla y para bolbelle en su juizio le davan cruelísimos tormentos y hazíanle abrir la boca con unos palos para hazelle pasar algunos brevajos, aplicados al remedio que avía menester, y dizían que de la misma manera quel hazía dar los tormentos, se los davan a él. Esto bien se deja entender era glosa fundada en pasión. En efecto, esto se le hazía, y nada no aprovechó a bolbelle en su juizio, y fue Dios servido que muriese. Y por no echalle en la mar dieron orden de abrille y sacalle las tripas, salalle y llevalle de aquella manera a tierra, que era a la Habana, en cuya demanda yvan. Tienen los marineros por cosa de prodijio llevar, quando navegan, cuerpo muerto de ombre en el navío, porque dizen es causa de munchas tormentas y no poder hazer su biaje; y como llebaban el cuerpo del doctor Carrillo, abierto y salado, lebantóseles algunas borrascas y entendierom lo causaba el difunto y dieron orden de echallo a la mar. Esto contradijo el liçençiado Muñoz y entretubo a los pilotos diziéndoles que ya estavan çerca de tierra y que allí le enterrarían. Con esto disimularon un día, y bisto que no çesaba, le rebolvieron en unas esteras, le liaron muy bien con un cavo le echaron a la mar para lleballe a jorro hasta tierra. Oy dezir que tampoco seçaba la tormenta aviendo hecho todas las dilijençias y que no bastava, le cortaron el cavo y se le dejaron en la mar (Tratado..., cp. XXXVIII, pág. 234)

Esta cadena de deslices históricos y narrativos del cronista son aprovechados en el relato de Fuentes para concentrar elementos. Primero, crea un personaje, Muñoz Carrillo, de los dos oidores; segundo, traslada a la acción narrativa la rapidez con la que, según Suárez de Peralta, llegan los detalles de la celebración del bautizo del hijo del marqués a la Audiencia; y tercero, funde en una escena los episodios de las detenciones del Marqués y de Alonso de Ávila, redundando en la homología entre ambos que la detención (y sus detalles) de Martín Cortés en la crónica sea la de los dos en el relato:

En este tiempo bino a parir la marquesa del Balle un hijo, con el qual se holgaron muncho los de la parte del marqués y luego trataron de hazer un torneo el día que le bautizasen. Ordenáronlo muy costoso, aunque no entró en él la jente de don Luis de Belasco, queran los que mejor lo podían hazer onrando más la fiesta. Ella se hizo con muncha música y gran aparato. Hizose un pasadizo desde unas bentanas del marqués a la yglesia mayor, todo enramado de flores y arcos triumfales y bosquería, con una puerta donde estaban dos cavalleros armados que defendían el paso, los quales combatían con los que trayan el niño a bautizar, y como los yban bençiendo los premdían, hasta que llegó el compadre y peleó con los que defendían el paso, y luego le allanó, y llebaron el ymfante y le bautizaron y le pusierom por nombre Pedro. Y a la buelta combatieron los unos y los otros la folla: çierto que pareçió bien. Este día salió a caballo un oydor a la jineta, que fue el dotor Horozco, y con él muncha jente, todos armados de secreto, porque no suçediese algo de lo tratado. La fiesta se acavó y ellos no entendían cosa de las que se trataban. Conbidó 
Alonso de Abila a la marquesa a una muy brava çena, y antes abía de aber, como lo ubo, una máscara de a cavallo. En todas estas ocasiones pensavan que en una abía de ser el alçamiento, y de secreto se armaban los oydores y los del rey, y andaban con aviso. Hizose la máscara muy regozijada y luego la çena, la qual fue muy cumplida y muy costosa, en la que se sirvieron unos basos, que allá llaman alcarrazas, y unos jarros de barro, y estos se hizieron en el pueblo de Alonso de Abila, en Quauhtitlan, que se haze allí muncho barro, y por gala les mandaron poner a todos unas çifras, desta manera: una ERRE y ençima una corona. Esta tenían todos los jarros y alcarrazas, y púsole Alonso de Abila, él por su mano, una alcarraza mayor que esotras, con esta çifra, a la marquesa. No creo abían bien empeçado la comida quando ya una de aquellas tenían los oydores, y dezían que quería dezir la çifra: reynarás. Huardáronla. Acavada esta çena, se fueron todos a sus casas, $y$, como e dicho, no se hablaba cosa que luego la sabían los juezes y la asentaban. [...]

Ya quellos tenían hecha su ymformaçión, entraron en acuerdo para determinar la prisión del, marqués y de sus hermanos don Luis Cortés, de la orden de Calatrava, y a don Martín Cortés, de la del señor Santiago, y a Alonso de Abila Albarado, y a Jil González Alvarado, su hermano. Y pareçe que Dios quiso quitar escándalo y aun la ocasión que se ofreçiera de muncho mal, si al marqués embiaran a prender a su casa con publiçidad. Permitió Nuestro Señor questando los oyores en el acuerdo en las casas reales, llegó vn correo con la nueba y cartas que abía benido un navío de abiso de España y el pliego de su magestad, que deseavan la benida deste nauío como la salvaçión. Es costumbre, quando llega pliego del rey, juntarse el bírrey y la audiençia a abrillo, y como llegó éste, en esta ocasión enbiaron a llamar al marqués con um portero, que biniese a hallarse al abrir el pliego. Y él bino luego a cavallo acompañado de sus criados. Estavan las casas reales llenas de jente que no cavían, las quales son grandísimas; y la plaça llena. Era un juizio, y todos a saver nuebas y cobrar cartas, muy descuydados de lo que después suçedió. Tenían los oydores puesta jente de los que más se fiavan en las salas y puertas, muy de secreto, y a don Françisco de Velasco, ermano del birrey dom Luis de Belasco, que bisitase la jente, y así lo hazía. Llegado que llegó el marqués y entró por las salas, yba díziendo: «Ea, que buenas nuebas emos de tener». Acuérdome que llebaba bestida una ropa de damasco larga, de berano, que era esto por julio, y ençima un herreruelo negro y su espada çeñida. En entrando en el acuerdo donde los oydores estaban, le reçibieron y dieron su asiento, y en sentándose se levantó un oydor, y se llegó a él y le dijo: "Déme vuesa señoría esa espada». Diósela y luego le dijo: «Sea preso por su magestad». Juzgue aquí cada uno quál quedaría el marqués y qué sentiría. Dizen que respondió: «¿Por qué?». «Luego se dirá». No entendió que aquella prisión era por lo que fue, sino que debía aber benido en aquel pliego probisión del rey para prendelle... (Tratado..., cp. XXXII, págs. 198-201)

Me repuse de estas afrentas celebrando, en cambio, el nacimiento de otro hijo mío y tratando de repetir las fiestas del año anterior cuando nacieron los mellizos: arcos triunfales y bosquería, música y gran aparato, y al cabo una máscara muy regocijada y luego una brava cena dada por mi compadre Alonso de Ávila, quien era señor del pueblo de Cuautitlán, especializado en jarritas de barro, a las que puso unas cifras así: una ERRE y encima una corona, y abajo una $S$, que significa: REINARÁS. Fue interrumpido el sarao por una comitiva armada a cuyo frente se encontraba un hombre que yo jamás había visto, cabezón y fornido, mal vestido y con ralos cabellos de mandrágora, coronando un rostro raspado como si se lavase con piedra pómez. Cómo contrastaba la grosería de su hábito con el atuendo parejo que para esa noche de gala adoptamos Alonso y yo. Noche de verano -julio de 1565- y los dos vestidos con ropa de damasco larga, y encima un herreruelo negro, con nuestras espadas ceñidas. Pues esto nos pidió el hombre con cara de piedra, cuadrado como un dado y pintado de color naranja por una naturaleza mezquina aunque justiciera: -Denme vuestras señorías sus espadas. Sean presos por su majestad. -¿̨Por qué? -dijimos con una sola voz, Alonso y yo. -Luego se os dirá -¿Por quién? -dijimos otra vez al unísono. -Por el licenciado Muñoz Carrillo, nuevo Oidor, que soy yo mismo -dijo esta aparición demasiado carnal para ser espanto y tomando el jarrito de Cuautitlán, lo arrojó con violencia al suelo. Éramos de barro nosotros y él, de piedra ( $L$ Los hijos del conquistador», págs. 102-103)

Indudablemente, en la construcción de esta efigie justiciera podemos encontrar ecos de la descripción que Torquemada ofrece de $\mathrm{Mu}$ ñoz, un «hombre muy severo y tan tieso que apenas movía la cabeza» por lo que «más parecía Dios airado, que hombre» ${ }^{32}$.

En «Los hijos del conquistador» será Martín II el que cuente la muerte del Oidor. En principio añade detalles a los ya ficticios del cronista, y no duda en multiplicar el enredo al enhebrar el óbito de Carrillo, después de un ataque de apoplejía, con el de Muñoz, tras ser recibido por Felipe II, para finalmento, $\mathrm{cp}$. XX, págs. 636 y 637 respectivamente.
Crónicas del siglo XVI, cuentos del siglo XX: Juan Suárez de Peralta a través de Carlos Fuentes VIRGINIA GIL AMATE 
Luis, hijo de Hernán Cortés y Anronia Hermosillo, nació hacia 1525. Fue legitimado por bula papal en 1529 con el nombre de Luis Altamirano. Viajará a España con su padre y el heredero, Martín Cortés, en 1940. Obtendrá la Orden de Calatrava. Regresó a Nueva España con su hermanastro Martín convertido ya en segundo marqués del Valle en 1562. Durante la conjura fue detenido junto con sus hermanos. Fue enviado a España en 1567 junto a su hermanastro el marqués, donde ambos fueron juzgados y condenados. Hernán Cortés lo desheredó poco antes de morir, bien por su casamiento con la sobrina de Bernardino de Tapia, Guiomar Vázquez de Escobar, bien por sus dispendios en Alemania. Cf. A. Muro Orejón, págs. 540 y 563 y J. L. Martínez, págs. 223-225.

34

S. Bolivar, "Carta de Jamaica», en Doctrina del Libertador, pról. Agusto Mijares, ed. Manuel Pérez Vila, Caracas, Biblioteca Ayacucho, núm. 1, 1985, pág. 104.
Crónicas del siglo XVI, cuentos del siglo XX: Juan Suárez de Peralta a través de Carlos Fuentes VIRGINIA GIL AMATE te, deshacer la maraña que comenzó en el Tratado..., desdoblando al Oidor en sus dos sujetos históricos y dándole a Muñoz la muerte soñada por Suárez de Peralta para Carrillo. Indirectamente la trama apunta que Martín II no es tan fácil de engañar como Martín I, pero reclama del lector un conocimiento histórico (y por supuesto de los intertextos manejados en el relato) sin el cual carece de sentido el artificio:

Devuelto a España en una goleta, al Oidor Muñoz Carrillo le dio un ataque de apoplejía, al leer una carta en la que el rey Felipe lo destituía, poniéndolo más cuadrado de lo que por natura ya era: «Os mandé a la Nueva España a gobernar, no a destruir». Perdió el habla y para curarlo, le abrían la boca con palos para que tomara sus brebajos. Murió este hombre de rostro lijado y hebras de mandrágora en la cabeza. Ya se sabe que estos homúnculos nacen al pie de las horcas. Pero a su sosias el oidor Muñoz para no echarlo al mar, lo abrieron, le sacaron las tripas y lo salaron, pues antes de morir logró decir: -Quiero que me entierren en El Ferrol. Se desataron tormentas y los marinos se amotinaron. Llevar un cuerpo muerto en navío trae mala suerte. Lo echaron al mar, bien liado y envuelto en esteras muy sucias llenas de brea. ( «Los hijos del conquistador», pág. 112)

Este procedimiento de concentración simbólica mostrado en la fusión de personajes abarca, aunque en menor medida no por ello menos significativo, la elisión de nombres que ocuparon un lugar en la trama histórica y como tales fueron destacados por Suárez de $\mathrm{Pe}$ ralta. Es el caso de Luis Cortés ${ }^{33}$ el hijo bastardo, criollo, díscolo y desheredado del conquistador, eliminado del relato para favorecer, con su ausencia, la dicotomía de la memoria histórica entre el criollo indolente y el mestizo resentido. A partir de esa polarización el relato avanza buscando puntos en común entre los hermanos. Para eso transita la senda de la ucronía imaginando qué pudo suceder durante el cautiverio de los hermanos Cortés, trastrocando la cronología histórica para que el tormento dado a Martín, el hijo de la Malinche, en la continuación del proceso, una vez que sus hermanos criollos habían sido enviados a España por el marqués de Falces, para ponerlos a salvo de la Audiencia de México, se produzca en la ficción durante un supuesto encierro compartido. Ello provoca que a los sucesos históricos e historiográficos que maneja el relato se unan otros hechos narrativos.

Uno pertenece a la acción del relato. El Oidor abofetea a Martín II provocando un movimiento de defensa en Martín I. Es esta una reacción instintiva y fugaz pero no desechable al indicar que las circunstancias pueden provocar la unión de estos dispares hijos de Cortés.

Otro es de índole lingüística. Los Martines poseen unos idiolectos identificadores, Martín I se expresa en un español que remite, geográficamente, al ámbito peninsular y, temporalmente, combina usos arcaicos y actuales pero con mayor predominio de los rasgos ligados al siglo XVI. Su característica más destacada radica en el tono con el que modula sus palabras, oscilante entre lo festivo, lo desinhibido, lo cursi o grosero pero siempre enfático, reproduciendo un estereotipo español; Martín II, por su parte, tiene un registro mexicano marcadamente coloquial, popular y contemporáneo, sus mensajes son incisivos y claros pero no eleva la voz, su tono es el del murmullo cuando expresa el fondo de sus pensamientos. Con ello, Martín II traspasa las fronteras de su marco histórico hacia un futuro al que aspira, al que ya ha llegado, en nuestro presente, su manejo de la lengua pero no las ideas que trasmite. Indudablemente la emancipación política que trata de hacer ver a su hermano («toma la tierra, olvídate de las cosas», pág. 94) llegó pero la discordia continuó porque los criollos que la gestaron se mantuvieron equidistantes en la negación de los pueblos enfrentados en la conquista - «No somos europeos, no somos indios» dirá Bolívar en la «Carta de Jamaica» ${ }^{34}-$, mientras Martín II se reconoce en la dualidad: «...mexicanito nuevo, indio y castellano como yo» (pág. 91).

Las formas de expresión se conectan con las mentalidades que representan y asumen todos los prejuicios que estas marcan, así el mestizo tiene una visión deformada de su hermano, lo cree el reflejo presentable del linaje paterno, lo considera refinado y sin embargo Martín I es, las más de las veces, inmoral, vulgar y ostentoso. No menos deformada es la imagen que de su hermano percibe el criollo, hasta el punto de atenuar o negar cualquier filiación con él. Partiendo de esta disparidad, se produce a medida que avanza la conversación, la confluencia lingüística cuando el criollo comienza a adoptar el léxico del mestizo hasta la 
asimilación de su registro, pero el hecho lingüístico no se acompaña de una cabal identificación humana:

Yo le dije a mi hermano Martín hijo de la Malinche: «El Oidor obra así para que Su Majestad sea muy servido y le haga, a su vez, muchas mercedes». Vio mi hermano, más astuto que yo, un signo del poder menguante de Muñoz Carrillo en todo esto. Y dijo también: «Pero tienes razón. Está quedando bien con el rey. Es un miserable lambiscón. Que vaya mucho y chingue a su madre». Jamás había oído esa expresión y supuse que era una de tantas que La Malinche le había enseñado a mi medio hermano. Me gustó, sin embargo, la palabrita. Se la apliqué con gusto a nuestro delator, Baltasar de Aguilar [...] Bastóle al rufián Baltasar de Aguilar, nuestro delator, entender que el Virrey procedía benévolamente con nosotros, para desdecirse de sus acusaciones con el fin de quedar bien con todos. Creo que entonces, sólo entonces, se encendió en mí la llama divina de la justicia. Pedí carearme con el hijo de la chingada -ya hablo como mi hermano- y Muñoz Carrillo decidió estar presente. Le eché en cara al traidor su proceder. Compungido se hincó ante mí y me pidió perdón. Le dije que nada perdonaría la muerte de Alonso de Ávila, mi más querido hermano... («Los hijos del conquistador», pág. 110)

La expresión común une a los que sin embargo no están dispuestos a reconocerse, volviendo los Martines a sus iniciales soliloquios al final del relato, en donde rumian sus particulares memorias históricas y suspenden el acceso a un futuro común y compartido: el criollo principal regresando a la desafecta España; el mestizo, enclaustrándose en su infancia al lado de su madre indígena. Los temas por los que ha discurrido la conversación quedan flotando, algún momento de unión tuvieron los hermanos pero en el plano histórico (aquel en el que fluye el tiempo) sigue separándoles el monstruo de la conquista, encarnado, en este relato profundamente alegórico, en una vieja contrahecha, otra hija de Cortés ${ }^{35}$, que lanza el término anulador de cualquier conocimiento cabal del origen:

La mujercita contrahecha [dice Martín II] me levanta violentamente la cabeza, agarrándome el pelo y me dice lo que yo esperaba oír:-Eres un hijo de la chingada. Eres mi hermano. («Los hijos del conquistador», págs. 104-105)

Frente al alto muro del malinchismo se erige otro hecho narrativo, de índole simbólica ${ }^{36}$, la presencia de un naranjo que contemplan o recuerdan los Martines, cuya imagen recorre este relato y todos los que conforman el volumen. Desarrolla la función de representar un tiempo circular y cíclico donde la imaginación enlaza diferentes hitos históricos, aunque su capacidad de significación es múltiple, al ser signo que alude tanto a la historia ${ }^{37}$ como a las letras mexicanas ${ }^{38}$ y es nuncio de que la naturaleza es mestiza en sí misma ${ }^{39}$, que los hechos históricos que provocaron el nacimiento de una entidad mestiza no deben ser negados ni ocultados, ni tampoco deben ser considerados distintivos de los hijos de Cortés, ya que en todas partes hay naranjos para disolver las intolerancias de las memorias colectivas: las de los que quieren reivindicar la gesta conquistadora o la de los que quieren vengar la suerte indígena. Los Martines no dejaban de apelar a un receptor más amplio que ellos mismos en su conversación, para esos implícitos oyentes se ha escenificado el diálogo, a ellos se les está diciendo: todo es mestizo, no sólo México. Moraleja que sin embargo no les sirve a los personajes, puesto que «Los hijos del conquistador» es un cuento, un ejercicio literario caracterizado por la elaboración simbólica de una idea. Mientras, la interesantísima crónica social de Suárez de Peralta, sin la cual no habría podido escribirse este relato, es menos inteligente, menos correcta y menos perfecta porque su prosa emanaba de los hechos vividos y en ella se volcaba su percepción de la realidad, con todas sus miserias y contradicciones, pero también con toda su particular verdad.

35

María, hija natural de Cortés y de una princesa azteca. CF. A. Muro Orejón, pág. 240.

\section{6}

Carlos Fuentes destacaba su categoría simbólica: «Es un símbolo de una naturaleza a la que hemos ultrajado constantemente y que, sin embargo, nos sobrevive hasta ahora», El País, de la conquista de la Nueva España de Bernal Díaz del Castillo: «También quiero decir como yo sembré unas pepitas de naranjas junto a otras casas de ídolos, y fue desta manera: que como había muchos mosquitos en aquel río, fuime a dormir a una casa alta de ídolos, e allí junto a aquella casa sembré siete $u$ ocho pepitas de naranjas que había traído de Cuba, e nacieron muy bien; parece ser que los papas de aquellos ídolos les pusieron defensa para que no las comiesen hormigas, e las regaban e limpiaban desque vieron que eran plantas diferentes de las suyas. He traído aquí esto a la memoria para que se sepa que estos fueron los primeros naranjos que se plantaron en la Nueva-España, porque después de ganado México e pacíficos los pueblos sujetros de Guazacualo, túvose por la mejor provincia, por causa de estar en la mejor comodación de toda la NuevaEspaña, así por las minas, que las había, como por el buen puerto, y la tierra de suyo rica de oro y de pastos para ganados; aeste efecto se pobló de los más principales conquistadores de México, e yo fui uno, e fui por mis naranjos y traspúselos, e salieron muy buenos», B. Díaz del Castillo, Historia verdadera de lo conquista de la Nueva España, ed. de Miguel León-Portilla, Madrid, Historia 16, 1984, tomo A págs. 104-105. La riqueza simbólica de este pasaje ya había sido destacada por Arturo Usla Pietri en su artículo "Las naranjas de Bernal» publicado en $\mathrm{EI} \mathrm{Na}$ cional, Caracas, 2 de febrero de 1969 y recogido en A. Uslar Pietri, La otra América, Madrid, Alianza, 1974, págs. 108-110.

39

«Trato de imaginar quién lo plantó, árbol mediterráneo, oriental, árabe y chino, en esto costa lejana de las Américas por primera vez»", reflexiona el protagonista del relato «Apolo y las putas», El naranjo, pág. 230.

12 de septiembre de 1993, pág. 30 .

\section{7}

«[El naranjo es] un fruto viajero, que tiene la forma del orbe, un fruto muy identificado con España», Idem.

38

No olvidemos que el naranjo remite a la Historia verdadera
Crónicas del siglo XVI, cuentos del siglo XX: Juan Suárez de Peralta a través de Carlos Fuentes VIRGINIA GIL AMATE 